\title{
Peertechz
}

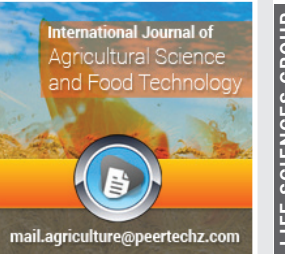

\section{Management and utilization practices of natural pasture in Western Ethiopia}

\author{
Kassahun Gurmessa*
}

Received: 02 March, 2021

Accepted: 05 April, 2021

Published: 06 April, 2021

*Corresponding author: Kassahun Gurmessa, Department of Animal Science, Salale University, P.O Box, 395 Nekemte, Ethiopia, E-mail:kassahun.hu@gmail.com

Keywords: Cutt and carry; Paddock feeding; Free grazing; Invassive plants

https://www.peertechzpublications.com

Check for updates

Department of Animal Science, Salale University, P.O Box, 395, Nekemte, Ethiopia

\section{Abstract}

A survey was conducted in highland and mid altitude areas of Horro and Guduru districts of Oromia Regional States, Western Ethiopia with the objective of assessing the management system and status of grazing land. A single-visit multi subject formal survey method was followed to gather data about grassland holding, management systems and livestock holding. A total of 210 respondents, 60 from highland and 150 households from mid altitude were selected and interviewed. Data were collected and analyzed using discriptive stastics. The result showed all households of highland and $89.3 \%$ of mid altitude had private grazing land. About $38.3 \%, 61.7 \%$ and $100 \%$ of surveyed households of highland and $17.33 \%, 64 \%$ and $98 \%$ of mid altitude households respectively have practice of cut and carry, paddock feeding and free grazing systems of grazing. The practice of natural pasture preservation in the form of closure was very common and practiced by $95 \%$ of highland and $67.33 \%$ of mid altitude surveyed households with overall mean of $75.2 \%$. Only few farmers, about $16.7 \%$ of highland and $29.33 \%$ of surveyed household of mid altitude have practice of hay making, while the practice of silage making was not known in both agro ecologies. The cause for the decreasing size of grazingland was ranked by the respondents. The major causes were listed as cultivation, expansion of towns (villagizations), investments and land allocation for social services (church, health services, offices). Accordingly the contribution of cultivation, expansion of twons, social services and investments were ranked as $1^{\text {st }}, 2^{\text {nd }}, 3^{\text {rd }}$ and $4^{\text {th }}$ respectively in highland, while cultivation,land allocation for social service, expansion of towns and investment ranked as $1^{\text {st }}, 2^{\text {nd }}, 3^{\text {rd }}$ and $4^{\text {th }}$ cause respectively in mid altitude. The cause for the deterioration of quality of grazing land was ranked similarily in both agro-ecologies. Accordingly disappearance of better and quality species was ranked $1^{\text {st }}$ cause, expansion of invasive plants $2^{\text {nd }}$ and depletion of soil as $3^{\text {rd }}$ cause. Improved herding system like herd spliting in which different species of different feeding habit are kept separately were less known in both agro-ecologies. Therefore improved forage development with good practices of conservation and good livestock management systems should be focus of intervention in both agro- ecologies.

\section{Introduction}

Livestock is an important and integral part the agriculture sector of Ethiopia. The subsector contributes about $16.5 \%$ of the national Gross Domestic Product (GDP) and 35.6\% of the agricultural GDP [1]. It also contributes $15 \%$ of export earnings and $30 \%$ of agricultural employment [2]. The livestock subsector currently support and sustain livelihoods for $80 \%$ of all rural population.

The population of livestock of Ethiopia is believed to be the largest in Africa and an estimate indicates that the country is a home for about 54 million cattle, 26 million sheep and 24 million goats, 1.9 million horse, 6.8 million donkeys, 0.4 million of mules and 0.9 million camels [3]. Of the total livetsock population of the country, about $75 \%$ of the cattle, $75 \%$ of the sheep and $34 \%$ of the goat population in Ethiopia are found in the highlands.
Despite high livestock population and existing favorable environmental conditions, the current livestock output of the country particularly in highland mixed crop livestock production system is little. For example the milk output per cow is estimated 1.3 litres per day [3]. This is associated with a number of complex and inter-related factors such as inadequate feed and nutrition, widespread diseases, poor genetic potential of local breeds, market problem, inefficiency of livestock development services with respect to credit, extension, marketing, and infrastructure [4-8].

The grassland region of Ethiopia accounts for some 30.5 percent of the area of the country and is most extensive in the western, southern and south-eastern semi-arid lowlands. On the more humid side, open grassland and grassland with some trees are common; grasses may cover as much as 90 percent of the area [9].

According to estimates of CSA 2013 about 57.5\%, 29.6 \%, 7.1 
$\%, 0.9$ and $0.2 \%$ animal feed is obtained from natural grazing, crop residues, hay, byproducts and improved feeds respectively. The natural pasture which is the contributer of major feed of livestock is characterized by seasonal fluctuation in total Dry Matter (DM) production and nutritional quality because of the distinct seasonal variation in plant growth, in relation to the annual rainfall pattern.

Given the importance of livestock in the country, the implementation of any livestock improvement program, and the efficient use of available feed resources demands understanding the prevailing status of feed resources and knowing practices of managing available feed resources of the rural community. Therefore, the present study was designed to assess the prevailing management system and status of grazinglands in Western highland and mid altitude areas of Ethiopia.

\section{Materials and methods}

\section{Description of the study area}

The study was conducted in Horro and Guduru districts of Horro Guduru Wollega Zone of Oromia Regional state, Western Ethiopia. The two districts are found between $36^{\circ}-37^{\circ} \mathrm{E}$ longitudes and $9^{\circ}-10^{\circ} \mathrm{N}$ latitude. They are found at altitude that ranges between $1450-3100$ and $1500-2450 \mathrm{~m}$. a. s.l. respectively for Horro and Guduru districts. The mean anoual rainfall ranges between $1350-1400 \mathrm{~mm}$. They have mean temprature that ranges between $12-32^{\circ} \mathrm{C}$ respectively $[10,11]$.

\section{Sampling procedures}

Assessment of grazingland management: A single-visit formal survey method [12] was followed to gather data about grassland holding and management systems of the study areas. Informal survey and group discussions were conducted with elders, key informants, and development agents working on the sites and district administrative officers. The information gathered through the above process were summarized and used as a basis to design a semi-structured questionnaire to quantify the most important parts of the study and the households were taken as a unit of analysis. Trained enumerators were used to assist in the collection of the data.

Pre test questionaire was used to study the type of grazingland owened, management, and status of grazing land. The districts was stratified into two using altitude as crateria $[9,13,14]$. Accordingly, the kebeles; which are the lowest administrative units in the study districts were grouped into two agro-ecological zones. Finally, a total of 210 households of which 60 from highland and 150 households were selected from mid altitude randomly based on the proportional number of households and the size of each stratum.

\section{Staistical analysis}

The computer software Stastical Package for Social Siences (SPSS of version 17.0) was employed to analyze data of survey work. An inidices were calculated for ranking data using the formula: Index $=\sum$ of [ 3 for rank $1+2$ for rank $2+1$ for rank 3] for overall reasons/criterias.

\section{Result and discussions}

\section{Household resources}

Average age of respondents, household size, land holding and use pattern and livestock holding of surveyed households is shown in Table 1. There was no significant difference in age of surveyed households. The average family member reported were similar $(\mathrm{P}>0.05)$ it was 7.1 for highland and 6.9 for mid altitude. The results of the analysis show that the overall average family size per household (hh) was 6.9 and was comparably higher than 5.6 members/households reported for Dendi districts of central part of Ethiopia [15] and comparably similar with 6.98 members reported for MuluSulula and lower than family size of 8.10 members reported for Degem [16]. The result of the present study also showed that the average landholding per hh of the two ago-ecologies were similar $(\mathrm{P}>0.05)$. There was significant difference $(\mathrm{P}<0.001)$ in livestock holding between highland and mid altitude areas of the present study areas. The large population of livestock holding of highland could be due to the prevailing larger area of grazing land and the probable less incidence of disease that could exist in highland (Table 1 and PRA result).

Type of grazing land: The type and owner ship of grazing lands of surveyed households of highland and mid-altitude areas of Horro and Guduru districts is dipicted in the Table 2 below. Two types ownership of grazing lands were identified, i.e. communal and private grazing land (Table 2). Due to expansion of cultivation land at the expense of communal grazing land and depletion of the remaining communal grazing land as a result of over grazing; the large segment of the community keep a portion of cultivable land for private grazing. As a result all surveyed households of highland and $89.3 \%$ of mid-altitude have their own grazingland. The average private grazing land size holding per surveyed households of highland

\begin{tabular}{|c|c|c|c|c|}
\hline \multirow{2}{*}{ Variables } & Highland & Mid altitude & Overall & Significance \\
\hline & MeantSE & MeantSE & MeantSE & \\
\hline Agre of respondents & $40.32 \pm 1.02$ & $41.39 \pm 0.91$ & $41.08 \pm 0.71$ & NS \\
\hline Family size $(\mathrm{N})$ & $7.12 \pm 0.31$ & $6.87 \pm 0.23$ & $6.94 \pm 0.18$ & NS \\
\hline Cultivation land (ha) & $3.70 \pm 0.26$ & $3.51 \pm 0.11$ & $3.56 \pm 0.11$ & NS \\
\hline Grazing land (ha) & $0.73 \pm 0.08$ & $0.47 \pm 0.03$ & $0.54 \pm 0.03$ & $\star \star \star *$ \\
\hline Total landholding & $4.43 \pm 0.26$ & $3.98 \pm 0.11$ & $4.11 \pm 0.11$ & NS \\
\hline Livestock number TLU & $13.00 \pm 0.60$ & $9.72 \pm 0.45$ & $10.65 \pm 0.38$ & $\star \star \star *$ \\
\hline
\end{tabular}

Table 2: Types and sizes of private grazingland of surveyed households.

\begin{tabular}{|c|c|c|c|}
\hline \multirow{2}{*}{ Description } & Highland & Mid-land & Overall \\
\cline { 2 - 4 } & $\mathbf{N}(\%)$ & $\mathbf{N}(\%)$ & $\mathbf{N}(\%)$ \\
\hline Private grazing land & & & \\
\hline Own & $60(100.0)$ & $134(89.3)$ & $194(92.4)$ \\
\hline Do not own & - & $16(10.7)$ & $16(7.6)$ \\
\hline Type of grazingland & & & \\
\hline Virgin & $3(5.0)$ & $47(31.3)$ & $50(26.04)$ \\
\hline Fallow & $57(95.0)$ & $87(64.9)$ & $142(74.00)$ \\
\hline N = Number of respondents & & & \\
\hline
\end{tabular}

Citation: Gurmessa K (2021) Management and utilization practices of natural pasture in Western Ethiopia. J Agric Sc Food Technol 7(1): 147-153. 
$(0.73 \pm 0.08 \mathrm{ha} / \mathrm{hh})$ was significantly higher $(\mathrm{P} \leq 0.05)$ than the holdings of mid-altitude $(0.47 \pm 0.03$ hectare) households (Table 1). Comparably the overall size of private grazing land size of the two agro-ecologies were higher than $0.3,0.4$ and 0.1 hectare reported for Diga, Jeldu and Fogera districts of Ethiopia located at Western, Central and Northern part of the country respectively $[15,17]$.

Majority of the type grazing land owned by surveyed household was fallow grass land followed by virgin grass land, which has shown variation according to the agro-ecological areas of repondents. About $95 \%$ of respondents of highland and $64.9 \%$ of surveyed households of mid-altitude possess fallow grazing land; whereas, only $5 \%$ highland and $31.3 \%$ of surveyed households of mid altitude possess virgin grassland (Table 2). This variation could be aroused due to the difference in intensity of cultivation. There is a social by in both agroecologies that prohibits shifting of virgin communal grazing land to private grazing land for private use. This social bylaw also forced individual households to reserve a portion of their private land that was previously used for cultivation for grazing and this bylaw allow private ownership of virgin grassland only if the grass land is surrounded by individual cultivated land and in accessible for others to drive their animal to this particular area which is locally called as "Gataa". Such type of grazing land when protected for long years will develop some bushs and trees that could be source of firewood and wood for construction. This social bylaw also allow Communal grazing of "Gataa", private grazing land and crop aftermath during dry season (January to May) when cattle are allowed to move anywhere to scavenge their feed without herding by herders. In this local areas this time is also known by name "Gadhisii" meaning livestock are released free of herding men for grazing (PRA result).

Grazing systems of grassland: The production system practiced in highland and mid altitude areas of Horro and Guduru districts is crop livestock production system [18]. However the grazing systems practiced in these areas varies according to season, size and type of grazing land and size of individual livestock. Extensive grazing, paddock feeding and Cut and carry system are listed as major grazing system of the two agro-ecologies. Furthermore, tether feeding is recently started by farmers owning very few livestock on road side (Table 3).

Extensive system of grazing is common practice of grazing for the entire highland and $98 \%$ of mid-altitude surveyed households. It is mainly practiced on communal grazing land throughout the grazing time. According to the perceptions of surveyed households, the reason for extensive grazing of communal grazing land is for two purposes; first this is for

Table 3: Feeding system of grass land.

\begin{tabular}{|c|c|c|c|c|c|c|}
\hline \multirow{2}{*}{ Agro-ecology } & \multicolumn{2}{|c|}{ Cut and carry } & \multicolumn{2}{c|}{ Paddock } & \multicolumn{2}{c|}{ Continuos grazing } \\
\cline { 2 - 8 } & Yes & No & Yes & No & Yes & No \\
\hline High ;and (N=60) & $23(38.3)$ & $37(61.7)$ & $33(55.0)$ & $27(45.0)$ & $60(100)$ & - \\
\hline Mid- land $\mathrm{N}=90)$ & $26(17.3)$ & $134(89.3)$ & $96(64.0)$ & $54(36)$ & $147(98.0)$ & $3(2.0)$ \\
\hline Overall $(\mathrm{N}=150)$ & $39(18.6)$ & $171(81.4)$ & $129(61.4)$ & $81(38.6)$ & $207(98.6)$ & $3(1.4)$ \\
\hline $\mathrm{N}=$ Number of respondents & & & & & \\
\hline
\end{tabular}

competitive exploitation of the communal land as there is no formal control over use of communal grazing land and the second purpose is to allow enough to for their private grazing lands' vegetations to attain more vegetative part and better forage quality which could be used for the time of scarcity.

Paddock system of grazing is mainly practiced on private grazing land. During the onset of rain both Private Grazing Land (PGL) and communal grazing lands are allowed for extensive grazing for short time. Then private grazing land is protected from grazing until it reaches maximum growth stage. During this time; animals are mainly allowed to graze on meager herbage found along roadside and in Communal Grazing Land (CGL). After the whole crop land is cultivated the privately owned enclosure is used for paddock feeding and cut and carry system. This starts at end of September to November in which cattles graze on communal land at morning to mid days, and then allowed for grazing protected private grazing land late afternoon. The paddock feeding system is common and practiced by about $55 \%$ of highland and $64 \%$ of surveyed households of mid altitude. This type of grazing system is common and reported for other parts of the country $[19,20]$ Figure 1.

The present study result also revealed that the practice of cut and carry system of feeding was less popular and practiced only by about $38.3 \%$ and $17.3 \%$ of surveyed household of highland and mid-altitude respectively. Such system of feeding is allowed mainly for sick, oxen and equines especially for horses.

Generally the present study revealed that natural pasture sustains livestock for about 6 months (June to December) unti cultivated crop land is harvested and open for grazing.This conforms to the general research report that natural pasture is one of the major sources of animal feed in the country $[3,9,20]$.

Practice and forms of conserving pasture: The practices and forms of uses and conservation of herbage from grassland known in the two agro-ecologies are summarized in Table 4. Of the total surveyed households about $83.3 \%$ of highland and $70.7 \%$ of mid-altitude either don't have experience of conserving pasture in the form of silage or hay for the time of forage scarcity. Enclosure of pasture seems to be more practiced among farmers having practice of conserving pasture. The present study also indicated that about $95 \%$ of surveyed households of highland and $67.3 \%$ of mid altitude enclose their private grazing land until it reach maximum biomass yield. This enclosure is used either for paddock feeding, cut and carry or for hay making. The result of present study showed that hay making was practiced only by $16.7 \%$ of households of highland and $29.3 \%$ of surveyed households of mid-altitude and also revealed none of the respondents of the two agro-ecologies has started or know silage making.

The enclosed grazing land is majorly used for paddock feeding which is traditionally known as 'Kuta' grazing. This type of grazing involves feeding a portion of enclosure first and then shifting to ungrazed portion after the first portion is well grazed and this will continues until the whole enclosure is well

Citation: Gurmessa K (2021) Management and utilization practices of natural pasture in Western Ethiopia. J Agric Sc Food Technol 7(1): 147-153. 


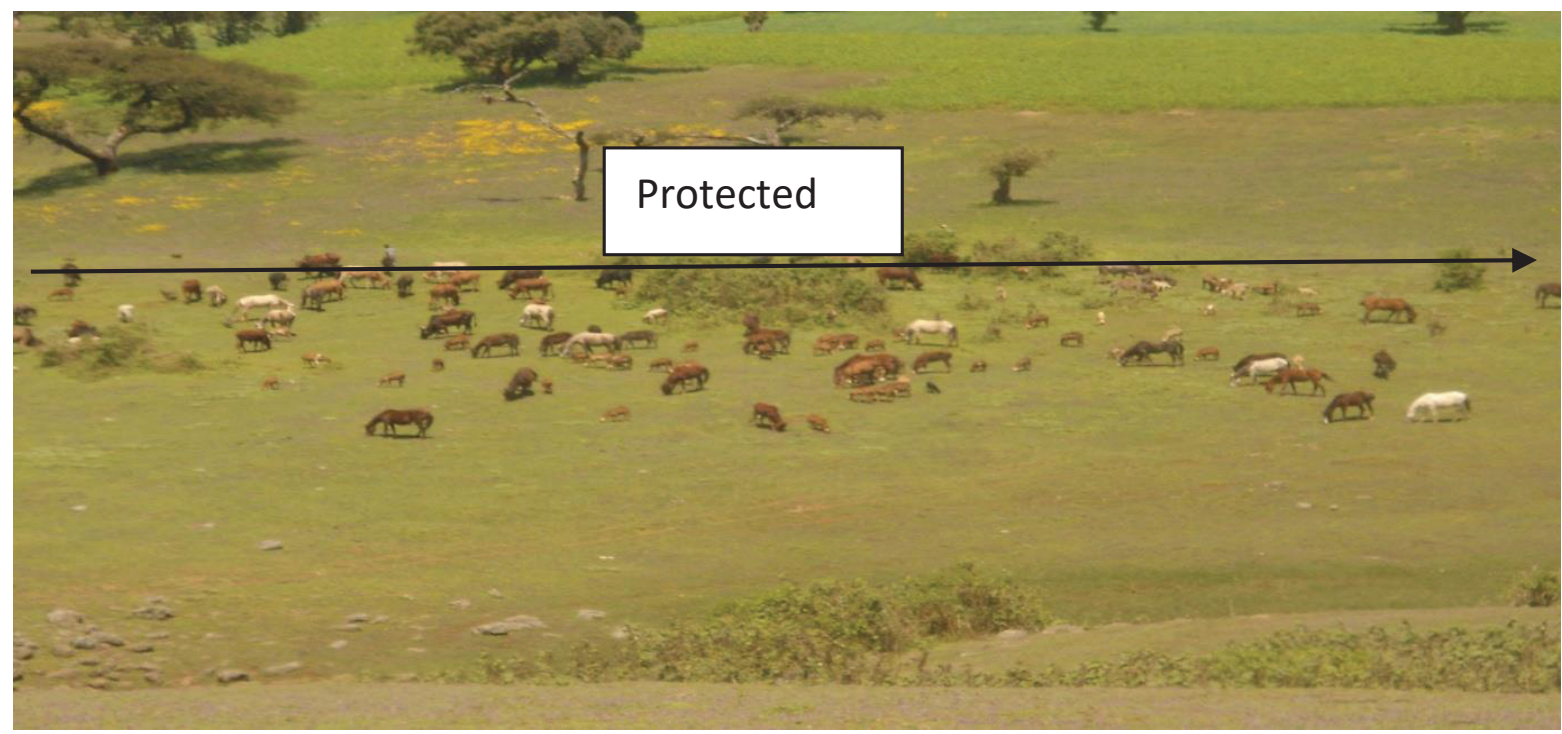

Figure 1: Paddock grazing.

grazed. In this system of grazing ('Kuta'system), priority of feeding is given according to the age, and species of the animal. Accordingly small ruminants and calves are allowed to graze first, followed by matured cattle and then equines are allowed to graze finally in mixed with other live stocks.

Feed prioritization and herding system: In both agroecologies of the present study areas surveyed households has reported that there is traditional knowledge of selective feeding their productive animals according to their economic importance, physiological status and their health. Accordingly oxen are the first, lactatining cows are the second and fattening animals are $3^{\text {rd }}$ prioritized in feeding and sick and pregnant cows are $4^{\text {th }}$ and $5^{\text {th }}$ respectively (Table 5 ). This selective feeding of productive animal is a good indication of their understanding of the role of proper feeding in enhanced productivity of their animal and need to be adopted in other parts of the country for better livestock sector improvement of the country.

\section{Farmers' perception on the status of grazing land}

Size of grazing land: The perception of surveyed households on status of grazing land for both agro-ecologies is presented in Table 6 below. According to the perception of respondents of the two agro-ecologies the allocation of grazing lands for cultivation, expansion of town, investment and expansion of social services were listed as the main causes for the decline of the size of grazingland. All rsepondents of highland and $99.3 \%$ of the mid altitude raised expansion of cultivation land as the first cause for the decreasing size of grazingland and the share of the rest reasons were minimal. Similar observations were also reporeted for Ginchi and Bosona districts of Ethiopia [2022 ]. This indicates that the demand for integration of improved forage development and crop production so as to sustain the lives of the poor farming communities of the areas. Quality of grazing land: almost all surveyed household of the two agroecologies believe that the quality of grazingland is decreasing (Table 6). Disappearance of nutritious and palatable species, expansion of invasive plants, and depletion of soil fetility were
Table 4: Practice of pasture conservation and forms of conserving

\begin{tabular}{|c|c|c|c|}
\hline Activities & High ;and $\mathbf{( N c = 6 0 )}$ & Mid highland $\mathbf{( N = 6 0 )}$ & Overall \\
\hline Enclosing & $57(95.0)$ & $101(67.3)$ & $158(75.2$ \\
\hline Conserve as hay & $10(16.7)$ & $44(29.3)$ & $54(25.7)$ \\
\hline Conserve as silage & - & - & - \\
\hline I don't conserve & $50(83.3)$ & $106(70.7)$ & $156(74.3)$ \\
\hline N = Number of respondents & & \\
\hline
\end{tabular}

Table 5: Feed priortization practiced by surveyed households of highland and mid highlands of Horro and Guduru districts.

\begin{tabular}{|c|c|c|c|c|c|c|c|}
\hline \multicolumn{2}{|c|}{ Agro -ecology } & $1^{\text {st }}$ & $2^{\text {nd }}$ & $3^{\text {rd }}$ & $4^{\text {th }}$ & $5^{\text {th }}$ & Index \\
\hline \multirow{5}{*}{ High land } & Oxen & 37 (61.7) & 23 (38.3) & - & - & - & 0.31 \\
\hline & Lactating & 23 (38.3) & 37 (61.7) & - & - & - & 0.29 \\
\hline & Fattening & - & - & $41(68.3)$ & 19 (31.7) & - & 0.18 \\
\hline & Sick & - & - & $21(35.0)$ & $39(65)$ & - & 0.16 \\
\hline & Pregnant & - & - & - & - & $\begin{array}{c}16 \\
(26.7)\end{array}$ & 0.02 \\
\hline \multirow{5}{*}{$\begin{array}{l}\text { Mid high } \\
\text { land }\end{array}$} & Oxen & $\begin{array}{c}121 \\
(80.7)\end{array}$ & $22(14.7)$ & $7(4.7)$ & - & - & 0.32 \\
\hline & Lactating & $25(16.7)$ & $\begin{array}{c}124 \\
(82.7)\end{array}$ & - & $1(0.7)$ & - & 0.28 \\
\hline & Fattening & $3(2.0)$ & $10(6.7)$ & $\begin{array}{c}118 \\
(78.7)\end{array}$ & $19(12.7)$ & - & 0.20 \\
\hline & Sick & $1(0.7)$ & $1(0.7)$ & $18(12.0)$ & $\begin{array}{c}130 \\
(86.7)\end{array}$ & - & 0.14 \\
\hline & Pregnant & - & - & - & - & $\begin{array}{c}55 \\
(36.7)\end{array}$ & 0.02 \\
\hline
\end{tabular}

reported to be the main cause respectively. In these areas, during the wet season, grazing lands contain a significant proportion of wild Trifolium species which is grazed prior to full blooming causing incidence of bloating which result the affected animals often death within a short period of time especially in mid wet season. Other invasive and noxious plants like Raphanus raphanistrum (gommene), Parthenium hysterophorus were also reported to be the most invedors. This conforms to the general idea that overgrazing of natural grazing lands results in invasion of unpalatable weeds and woody plants [9,23-25]. 
Table 6: Status of the size and quality of grazing land and reasons for change as percieved by surveyed households.

\begin{tabular}{|c|c|c|c|c|c|c|c|c|}
\hline \multirow[b]{2}{*}{ Reasons } & \multicolumn{3}{|c|}{ A- Size of Grazing } & \multicolumn{5}{|c|}{ Ranked reasons for the decrease } \\
\hline & Increasing $\mathbf{N}(\%)$ & No change N (\%) & $\begin{array}{c}\text { Decreasing } \\
\text { N (\%) }\end{array}$ & $1^{\text {st }} \mathrm{N}(\%)$ & $\begin{array}{c}2^{\text {nd }} \\
N(\%)\end{array}$ & $\begin{array}{c}3^{\text {rd }} \\
N(\%)\end{array}$ & $\begin{array}{c}4^{\text {th }} \\
N(\%)\end{array}$ & INDEX \\
\hline High land & - & - & $60(100)$ & & & & & \\
\hline Cultivation & - & - & - & $60(100)$ & - & - & - & 0.40 \\
\hline Expansion of twon/villages & - & - & - & - & $42(70.0)$ & $4(6.7)$ & $14(23.3)$ & 0.247 \\
\hline Investment & - & - & - & - & $3(5.0)$ & $16(26.7)$ & $41(68.3)$ & 0.137 \\
\hline Social service & - & - & - & - & $15(25.0)$ & $40(66.7)$ & $5(8.3)$ & 0.216 \\
\hline Mid high land & - & $1(0.7)$ & $149(99.3)$ & & & & & \\
\hline Cultivation & - & - & - & $149(99.3)$ & $1(0.7)$ & - & - & 0.399 \\
\hline Expansion of twon/villages & - & - & - & - & $26(17.3)$ & $97(64.7)$ & $27(18.0)$ & 0.199 \\
\hline Investment & & & & $1(0.7)$ & $9(6.0)$ & $33(22.0)$ & $107(71.3)$ & 0.136 \\
\hline \multirow[t]{2}{*}{ Social service } & - & - & - & - & $114(76.0)$ & 20 (13.3) & $16(10.7)$ & 0.265 \\
\hline & \multicolumn{3}{|c|}{ B- Quality of grazing land } & $1^{\text {st }}$ & $2^{\text {nd }}$ & $3^{\text {rd }}$ & & \\
\hline High land & - & $1(1.7)$ & $59(98.3)$ & - & - & - & - & INDEX \\
\hline Disappearance of better spps. & & & & $50(83.3)$ & $6(10.0)$ & $4(6.7)$ & - & 0.641 \\
\hline Expansion of invasive plants & & & & $4(6.7)$ & $46(76.7)$ & $10(16.7)$ & - & 0.317 \\
\hline Depletion of soil & & & & $6(10.0)$ & $8(13.3)$ & $46(76.7)$ & - & 0.222 \\
\hline Mid high land & & $2(1.33)$ & $148(98.7)$ & & & & & \\
\hline Disappearance of better spps. & & & & $75(50.0)$ & $43(28.7)$ & $32(21.3)$ & & 0.381 \\
\hline Expansion of invasive plants & & & & $48(32.0)$ & $62(41.3)$ & $40(26.7)$ & & 0.342 \\
\hline Depletion of soil & & & & $27(18)$ & $45(30.0)$ & $78(52.0)$ & & 0.277 \\
\hline
\end{tabular}

Therefore weed control and weeds are major problems in both perennial and annual pasture and forage crops and needs to be controlled.

Figure 2. Show the disappearing and endangered herbaceous species of grassland as listed by surveyed households. About 10 important and common species of herbacious plants were listed by surveyed house holds. Of which nine were grasses and one anual legume. Among them Cynodon dactylon, Pennisetum clandestinum and pennisetum sphacelatum were listed as endangered species by large percent of respondents due to overgrazing and natural calamities.

\section{Practice of establishing improved pasture}

One of the best opportunities for highland farmers to use land efficiently would be through the introduction of improved pasture and forages in the farming system. Figure 3 below shows the percentage of surveyed households experiencing cultivation of improved forages on grass land. The most cultivated improved forages in the present study areas were listed and described by surveyed households. Rhodes grass, Oats, Elephant grasses and alfalfa were among the most frequently cultivated and used in both agro-ecologies. Among surveyed households only $28.3 \%$ of highland and $6 \%$ of mid altitude households have started cultivation of improved pasture. The experience seems higher in highland than mid altitude, which could be varied due to the prevailing larger size of private grazing land and intensive cultivation of crop in highland community.

\section{Conclusion}

Grassland is the major feed resources for livestock in the study areas especially during rainy season June to December. The trend of reserving grazing land for private use was entirely practiced by all respondents of highland and by majority of mid-altitude residents. Free grazing on both communal and

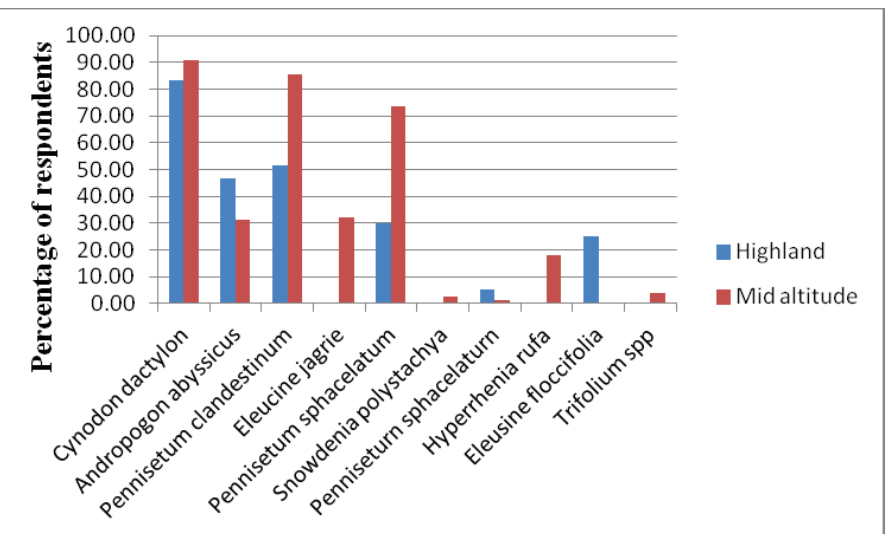

Figure 2: List of endangered sppecies of grass land as described by farmers.

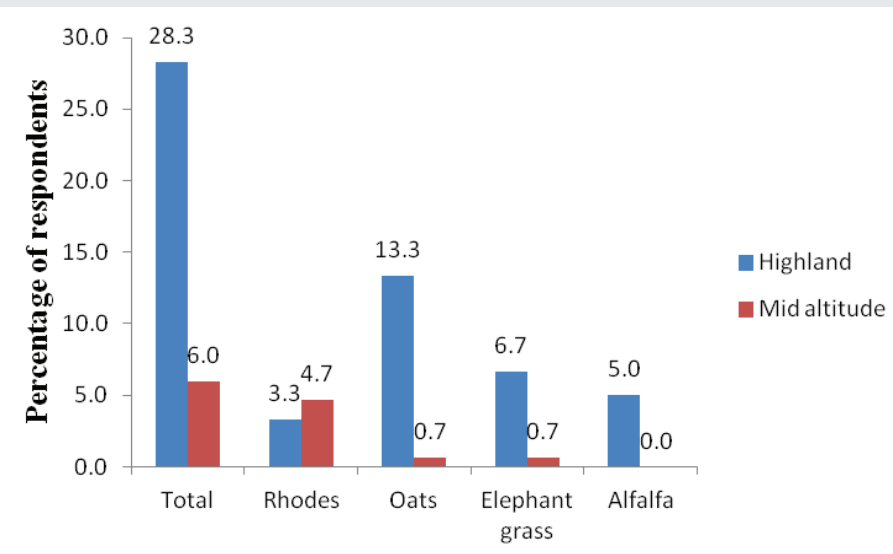

Figure 3: Percentage of respondent's expriencing cultivation of improved forage on pasture land.

private grazing land and paddock feeding on private grazing land were the major grazing system. While, Cut and carry system practiced by only few household of the study areas. The practice of pasture conservation in the form of silage was totally absent in agro-ecologies while, few respondents have started 
conserving pasture in the form of hay and the use of pasture land in the form enclosure was very common in both agroecologies. Almost all surveyed household agree that the size of grazing lands were drasticaly decreased due to expansion of cultivation land, investments and expansion of cultivation land and some social service. They blieve that the quality of grazing land has also decreased as a result of disappearance of highly palatible and quality species, invasions of invasive weeds and depletion of the soil. Mixed species herding was practiced in both agro-ecologies. This entails herding of animals of different feeding habit (grazers and browsers) together. Therefore, based on the result the following recommendations are forwarded for improving pastureland and livestock development in the areas.

- The practice of land allocation for private grazing should be encouraged with the improved feeding systems.

- Conservation of pasture in the form of silage and hay should be a close intervention area to mitigate feed shortage that might be the cause for low performance of livestock especially during dry season.

- There is a need to integrate crop with high yielding and quality forage species to improve feed shortage that might arise as a result of cultivation, investment and allocation of land for social services and decrease in the quality of grazing land.

- The indiscriminate continuous grazing and absence of control over the communal grazing land needs due attention through improved management system and participation of the community.

\section{Acknowledgement}

My great thanks and gratitude goes to Wollega University of Ethiopia and farmers involved in the survey.

\section{References}

1. Metaferia F, Cherenet T, Gelan A, Abnet F, Tesfay A, et al. (2011) A review to improve estimation of livestock contribution to the national GDP. Addis Ababa, Ethiopia: Ministry of Finance and Economic Development, Ministry of Agriculture. Link: https://bit.ly/3ur1tSu

2. Behnke R (2010) The Contribution of Livestock to the Economies of IGAD Member States: Study Findings, Application of the Methology in Ethiopia and Recommendations for Further Work, IGAD LPI Working Paper 02-10. Link: https://bit.ly/3wpqXSh

3. CSA (2013) Federal democratic republic of Ethiopia Central statistical agency Agricultural sample survey. Volume II Report on Livestock and livestock characteristics (private peasant holdings).

4. Benin S, Ehui S, Pender J (2003) Policies for livestock development in the Ethiopian highlands. Environ Dev Sustain 5: 491-510. Link: https://bit.ly/3cXhcmJ

5. Jabbar M, Negassa A, Gidyelew T (2007) Geographic distribution of cattle, shoats populations and their market supply sheds in Ethiopia, Discussion paper No. 2. Improving Market opportunities ILRI (International Livestock Research Institute), Nairobi, Kenya 54. Link: https://bit.ly/3sXqvlH

6. Negassa A, Rashid S, Gebremedihin B (2011) Livestock Production and Marketing. ESSP II working paper 26. International Food policy Research Institute/Ethiopia strategy Support programll, Addis Ababa, Ethiopia. Link: https://bit.ly/3rUtbFw
7. Solomon A, Workalemahu A, Jabbar MA, Ahimed MM, Hurissa B (2003) Socioeconomic and Policy Research working paper 52. Kenya. ILRI (International Livestock Research Institute), Nairobi, Livestock marketing in Ethiopia: A review of structure, performance and development initiatives software: Release 12. StataCorp LP, College Station, TX.

8. Tolera A (2012) Potential for Development of Alternative Feed Resources in Ethiopia. An Assessment Report prepared for ACDI/VOCA. Addis Ababa Ethiopia 20.

9. Mengistu A (2006) Pasture and Forage Resource profiles of Ethiopia. Ethiopia/ FAO. Addis Ababa, Ethiopia 19.

10. Mekonen A, Dessie T, Mekasha Y (2012) Performance evaluation of and design of breeding strategy for Horro cattle breed in Western Oromia, Ethiopia. A dessertation submitted to Animal and Range Sciences of Haramaya University.

11. Hunde D, Beyene F, Duguma G (2013) Early growth and reproductive performance of Horro cattle and their F1 Jersey crosses in and around Horro-Guduru livestock Production and Research Center, Ethiopia. Science, Technology, and Art Journal 2: 134-141. Link: https://bit.ly/3dzQAqR

12. ILCA (International Livestock Center for Africa) (1990) Livestock systems research manual. No. 12, section 1. Working document. ILCA. Addis Ababa, Ethiopia 8. Link: https://bit.ly/3woBBIO

13. MoA /National Livestock Development Program (1998) Ethiopia, Working Paper 4 - National Resources and the Environment.

14. Ministry of Agriculture (MoA) (2000) Agroecological Zonations of Ethiopia Addis Ababa, Ethiopia.

15. Duguma B, Tegene A, Hegde BP (2012) Smallholder Livestock Production System in Dendi District, Oromia Regional State, Central Ethiopia. Global Veterinaria 8: 472-479. Link: https://bit.ly/39J9N8c

16. Kelay BD, Mlynek J, Nagel U, Herzog H (2002) Analyses of Dairy Cattle Breeding Practicesin Selected Areas of Ethiopia. Dissertation submited to eingerichtet an der Landwirtschaft-Gärtenerischen Fakultät der Humboldt-Universität zu Berlin.Link: https://bit.ly/3wyEBme

17. Eeba B, Haileselase A, Animut G (2012) Study of smallholder farms livestock feed sourcing and feeding strategies and their implication on livestock water productivity in mixed crop-livestock systems in the highlands of the Blue Nile basin, Ethiopia. A Thesis Submitted to the School of Animal and Range Sciences, School of Graduate Studies Haramaya University. Link: https://bit.ly/39Lk7wq

18. Kassahun G, Taye T, Adugna T, Fekadu B, Solmon D (2015) Quantifying Herbage Mass, Composition and Feed Value of Grass Land as Influenced by Altitude in Western Highlands of Ethiopia. Journal of Biology, Agriculture and Healthcare 5: 2224-3208. Link: https://bit.ly/39Lkcjl

19. Bogale S, Melaku S, Yami A (2008) Influence of rainfall pattern on grass/ legume composition and nutritive value of natural pasture in Bale Highlands of Ethiopia. Livestock Research for Rural Development 20. Link: https://bit.ly/3dy6fa6

20. Hassen A, Ebro A, Kurtu M, Treydte AC (2010) Livestock feed resources utilization and management as influenced by altitude in the Central Highlands of Ethiopia. Link: https://bit.ly/3wqHi9n

21. Gizachew L (2002) Crude protein and mineral status of Forages grown on pelvic vertisol of Ginchi, central highlands of Ethiopia. PhD dissertation Presented to the University of the Free State, Bloemfontein.

22. ICRA (2001) The shift to Cereal Mono-cropping: a Threat or a Blessing?" Toward Sustainable Agricultural Production in the Wheat-barley Farming System in the Highlands of Southeast Oromia, Ethiopia. ICRA- 2001 Ethiopian Team, Working Document Series 92, Ethiopia 189. 
23. Peter J, Alvaro D (2004) Understanding Relative Feed value (RFV) and Relative Forage quality (RFQ). Collegeof Agriculture and Biological Science/ South Dakota State University/ USDA. Link: https://bit.ly/3ukDuEs

24. Statistical Packages for the Social Sciences (SPSS) (1996) Cary, North Carolina, USA.
25. Sileshi Z, Bediye S, Gebrehiwot L, Tekletsadik T (1995) Effect of harvesting stage on yield and quality of natural pasture in the central highlands of Ethiopia. In: Proceedings of the $3^{\text {rd }}$ Annual Conference of the Ethiopian Society of Animal Production Addis Ababa, Ethiopia 316 - 322. Link: https://bit.ly/3mlvZuc
Discover a bigger Impact and Visibility of your article publication with Peertechz Publications

\section{Highlights}

* Signatory publisher of ORCID

* Signatory Publisher of DORA (San Francisco Declaration on Research Assessment)

* Articles archived in worlds' renowned service providers such as Portico, CNKI, AGRIS, TDNet, Base (Bielefeld University Library), CrossRef, Scilit, J-Gate etc.

* Journals indexed in ICMJE, SHERPA/ROMEO, Google Scholar etc.

* OAI-PMH (Open Archives Initiative Protocol for Metadata Harvesting)

* Dedicated Editorial Board for every journal

* Accurate and rapid peer-review process

* Increased citations of published articles through promotions

* Reduced timeline for article publication

Submit your articles and experience a new surge in publication services (https://www.peertechz.com/submission).

Peertechz journals wishes everlasting success in your every endeavours.

Copyright: @ 2021 Gurmessa K. This is an open-access article distributed under the terms of the Creative Commons Attribution License, which permits unrestricted use, distribution, and reproduction in any medium, provided the original author and source are credited. 